\title{
SIMULATION MODEL TO PREDICT PROJECT TIME AND COST PERFORMANCE OF INCENTIVE/DISINCENTIVE CONSTRUCTION PROJECTS
}

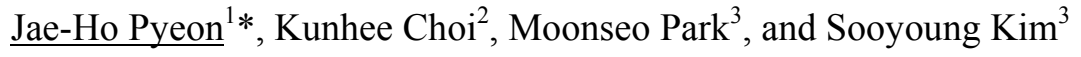 \\ ${ }^{1}$ Department of Civil and Environmental Engineering, San Jose State University, California, USA \\ ${ }^{2}$ Department of Construction Science, Texas A\&M University, Texas, USA \\ ${ }^{3}$ Department of Architecture Engineering, Seoul National University, Seoul, Korea \\ *Corresponding author (jae.pyeon@sjsu.edu)
}

\begin{abstract}
In highway construction, Incentive/Disincentive (I/D) contracting provisions have been widely used to motivate the contractor for early completion of roadway construction in the United States. Although I/D provisions are one of the owner's useful management tools, there is no systematic decision support system for the selection of I/D projects. This paper presents a project time and cost performance simulation model to assist project planners and managers by providing a complete picture during the I/D contracting decision-making process of possible performance outcomes with probabilities based on historical data. This study was performed by collecting transportation construction project data. The collected project data from the Florida Department of Transportation were evaluated using time and cost performance indices and then statistical data analysis was performed to identify important factors that influence construction project time performance. Using Monte Carlo simulation procedures, this study demonstrated a methodology for developing an I/D project time and cost performance prediction model. User-friendly visual interfaces were developed to perform the simulation and report results using Visual Basic Application programming. The developed model was validated using additional cases of transportation construction projects.
\end{abstract}

Keywords: Incentive/Disincentive, Alternative Contracting, Decision Support Systems, Project Performance, Highway Construction

\section{INTRODUCTION}

$\mathrm{I} / \mathrm{D}$ contracting experiences in many states have been evaluated in terms of time and cost performance $[1,2,3]$. It has been found that there were substantial project time savings from many project cases. However, it has also been reported that there have been many inefficient cases using $\mathrm{I} / \mathrm{D}$ contracting for various transportation construction projects. For instance, many contractors were able to achieve maximum incentives without reducing the original contract time since the incentives were generally paid based on the extended contract duration, which included time extensions, supplemental agreement days, and weather days. These inefficiencies can often be attributed to a poor understanding of the factors that affect the suitability of using I/D contracts. Therefore, a better

understanding of the relationships among such factors as contract types, project types, project sizes, project locations, incentive amounts, and other similar factors is key to providing clear guidance for the better use of incentive contracting [4].

The purpose of this research project is to develop a model to enhance the decision-making process for the selection of I/D projects. The proposed decision-making model would be a useful tool to effectively and efficiently assist state and federal construction project planners and managers to become more knowledgeable and effective in their decision-making.

\section{METHODOLOGY}


This research was performed by collecting transportation construction project data. The collected project data from the Florida Department of Transportation (FDOT) were evaluated using time and cost performance indices and then statistical data analysis was performed to identify important factors that influence construction project time performance. Using beta distributions of the input variables for the key factors, a decision support model was developed for prediction of I/D project time and cost performance. Finally, a new set of I/D contracting project cases was used to validate the developed decision support model. The cross-functional flowchart below (Figure 1) briefly illustrates the model development process.

\begin{tabular}{|c|c|c|c|c|}
\hline \multicolumn{5}{|c|}{ I/D Contracting Project Performance Prediction Model } \\
\hline \multirow{4}{*}{$\begin{array}{l}0 \\
0 \\
0 \\
0 \\
0 \\
0\end{array}$} & $\begin{array}{c}\text { Data } \\
\text { Collection }\end{array}$ & $\begin{array}{c}\text { Data } \\
\text { Analysis }\end{array}$ & $\begin{array}{c}\text { Model } \\
\text { Development }\end{array}$ & $\begin{array}{c}\text { Model } \\
\text { Validation }\end{array}$ \\
\hline & $\begin{array}{c}\text { 1/D Contracting } \\
\text { Project } \\
\text { Database }\end{array}$ & $\begin{array}{c}\text { Input } \\
\text { Variable } \\
\text { Selection }\end{array}$ & $\begin{array}{c}\begin{array}{c}\text { Decision } \\
\text { Suport Model } \\
\text { Development }\end{array} \\
\end{array}$ & $\begin{array}{c}\text { Model } \\
\text { Validation }\end{array}$ \\
\hline & \begin{tabular}{|} 
Transportation \\
Construction \\
Project Data
\end{tabular} & $\begin{array}{c}\text { Statistical } \\
\text { Analysis }\end{array}$ & $\begin{array}{l}\text { Modeling } \\
\text { Process } \\
\text { Using Beta } \\
\text { Distribution }\end{array}$ & $\begin{array}{l}\text { Additional I/D } \\
\text { Project Data } \\
\text { Inputs }\end{array}$ \\
\hline & & $\begin{array}{l}\text { Project Time } \\
\text { and Cost } \\
\text { Performance } \\
\text { Evaluation }\end{array}$ & & \\
\hline
\end{tabular}

Fig. 1 Model Development Process Flowchart.

Figure 2 shows a screen snapshot of a dialog box of project variable selection for a roadway resurfacing project. The input dialog box includes seven options of project variable selections.

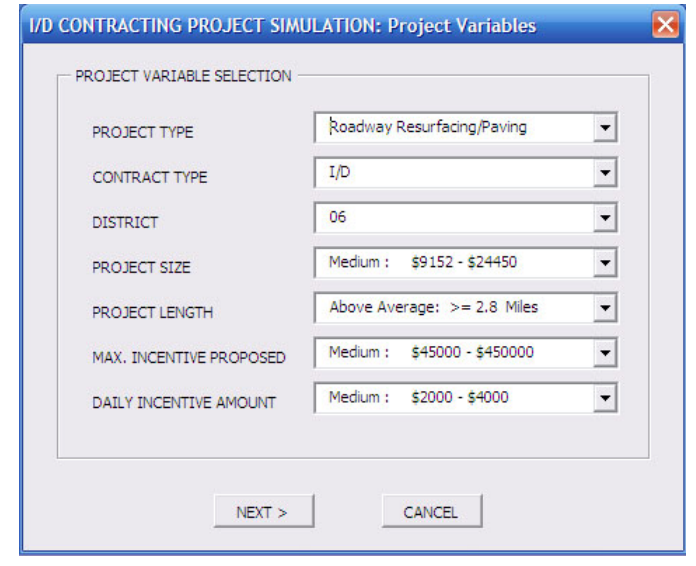

Fig. 2 Project Variable Selection Dialog Box.

The developed model was validated using 30 additional project cases of transportation construction. Considering the following results, the performance prediction range of the developed model were fairly accurate. For instance,
OTPI simulation results used only 18 to $49 \%$ of the historical OTPI data range in order to predict the actual OTPI value for each case and approximately $93 \%$ of cases were within the predicted range.

\section{CONCLUSIONS}

This study demonstrated a methodology for developing an I/D project time and cost performance prediction model using Monte Carlo simulation. The developed model was validated using 30 additional project cases of transportation construction. In summary, more than $93 \%$ of cases were fallen within the predicted performance range. In conclusion, the developed model applied to I/D contracting projects will become a useful tool to assist the project planners during the decision-making process and will promote the efficient use of I/D contracting, which will benefit the public by saving their travel time from construction delays.

\section{ACKNOWLEDGMENTS}

The authors would like to express their gratitude to the Mineta Transportation Institute for the financial support and to the FDOT for providing valuable inputs.

\section{REFERENCES}

[1] American Association of State Highway and Transportation Officials, "Primer on Contracting for the Twenty-first Century," Report, AASHTO Subcommittee on Construction, Fifth Edition, Washington, D.C., 2006.

[2] Ellis, R., Pyeon, J., Herbsman, Z., Minchin, E., \& Molenaar, K., "Evaluation of Alternative Contracting Techniques on FDOT Construction Projects.” Final Report, FDOT, Tallahassee, Florida, 2007.

[3] Herbsman, Z. "A+B Bidding Method - Hidden Success Story for Highway Construction." Journal of Construction Engineering and Management, 121(4), 430-437, 1995.

[4] Pyeon, J., "Development of a Simulation Model to Predict the Impact of Incentive Contracts on Transportation Construction Project Time Performance." Ph.D. Dissertation, University of Florida, Gainesville, FL, 2005 